\title{
On the Possible Way of Solving the Problem of Coastal Protection in the Preserve Tauric Chersonesus
}

\author{
V.F. Udovik, S.Yu. Mikhailichenko, Yu.N. Goryachkin \\ Marine Hydrophysical Institute, Russian Academy of Sciences, Sevastopol, \\ Russian Federation \\ e-mail: udovik_uvf@mhi-ras.ru, liham@rambler.ru,yngor@yandex.ru
}

\begin{abstract}
Reasons and consequences of coast destruction in the Preserve Tauric Chersonesus included in the list of UNESCO World Heritage Sites are considered.Wind waves are the basic hydrodynamic factor leading to the destruction of the ancient city coast. The most significant retreat of the cliffs and the intense destruction of archaeological sites are observed in the northern sector of the reserve territory. This sector of the coast can be identified as a priority one for taking complex coastal protection measures. Conceptual principles of creating coastal protecting structures permitting to retain the coast historical landscape are analyzed. The wind wave fields nearby the Chersonesus ancient settlement coast are numerically simulated with high spatial resolution using the SWAN model based on the method of nested grids. At the same wind velocity the most intense waves are generated by the northwestern wind. Wave height, calculated for wind velocities of 15 and $25 \mathrm{~m} / \mathrm{s}$ immediate close to the coastline vary less considerably than in the seaward part of the water area. The wind wave fields are simulated under various variants of arranging hydrotechnical structures on the Black Sea adjacent area. The main coastal protection installations, which should provide damping storm surge energy reaching the shore, were considered the underwater breakwaters placed roughly parallel to the coastline. When running a series of numerical experiments the length and number of breakwaters, as well as the distance from the shore to the place of their location ranged. The schemes of allocation the submerged breakwaters are proposed which both provide effective energy dissipation of storm waves approaching the coastline and retain possibility of water exchange with the adjacent waters during the periods of weak winds.
\end{abstract}

Keywords: wind waves, coastal protection, the Preserve Tauric Chersonesus, SWAN model, submerged breakwaters, the Black Sea.

DOI: 10.22449/1573-160X-2016-2-24-33

(c) 2016, V.F. Udovik, S.Yu. Mikhailichenko, Yu.N. Goryachkin

(c) 2016, Physical Oceanography

Introduction. Destruction of the Preserve Tauric Chersonesus coast, situated within the boundaries of Sevastopol and included in the list of UNESCO World Heritage Sites, leads to the reduction of the ancient city area, the complete demolition of the architectural details of archaeological and historical monuments, which determines the urgent need for complex coast protection measures.

The effectiveness of the marine coastal protection is largely dependent on compliance with the fundamental conceptual principles developed on the basis of the experience of hydraulic structure construction under various conditions [1]. Developing and implementing the coastal protection projects in the locations of the cultural heritage objects, special attention should be paid to the principle of the maximum possible preservation of the existing natural landscape under the given conditions.

The Chersonesus coastal protection projects offered earlier were declined primarily because of the expected significant changes in the appearance of the coasts. See in [2] the example of such project. The technical solution of the aforementioned project was based on the use as the main constructive units the stone rip-rap, protective seawalls, berms and banquettes constructed of boulders, ferro-concrete blocks and shaped bodies, which, if implemented, could lead to the transformation of the preserve coast in the industrial landscape. It is obvious that the development of the optimum variant of the coastal protection project for the object of great social and economic importance is only possible as a result of a comprehensive approach to solving problems. 
It should include carrying out the necessary amount of research and survey works, as well as attracting world experience in the planning and implementation of coastal protection measures under these conditions.

The performed research was aimed to prepare the scientific advice, which can be used to develop Tauric Chersonesus coastal protection project, allowing preserving the ancient city coast historical landscape and the adjacent Black Sea water area. This paper presents the results of numerical modeling of the wind wave fields under various variants of arranging hydraulic structures.

Physical and geographical conditions. The ancient settlement of the Preserve Tauric Chersonesus is located on the promontory of the Heracleian peninsula coastline between the Karantinnaya and Pesochnaya Bays. The total length of the Chersonesus sea border is about $1800 \mathrm{~m}$. The greatest part of the coast is steep cliffs mainly of limestone of different densities which go directly to the water line. In the indentations at the foot of cliffs there are the areas of the exposed bench or narrow attached beaches ( $5-8 \mathrm{~m}$ width) with incomplete profile, composed of landwaste formed mainly as a result of local coastal erosion.

The main hydrodynamic factor leading to the ancient settlement coastal destruction is the wind waves. The width of the existing beaches is obviously insufficient to extinguish the energy of storm waves. Predominance of pebbles and larger fractions in the beach-forming material composition increases the draining effect during the action of waves at their destruction that leads to rise of low amplitude wave (to $2-3$ balls) energy dissipation. However, under the strong storms, in addition to the basic hydrodynamic load, the cliffs are exposed to the intense bombardment of the rudaceous rock material conveyed by the fluid flow, which increases the destructive effect of large amplitude waves. As a result, wavecut notches are formed everywhere, intensifying the natural coastal destruction in the form of landing slips and landslides.

Over the long history of Chersonesus the erosion rates in the various parts of the coast have undergone certain changes. The total retreat of the coast for 2,000 years according to different estimates is about $25 \mathrm{~m}$ average, and in some areas it reaches $40-45 \mathrm{~m}$. Corresponding decrease of the urban development area within the defensive walls is about 7.5 - 8 ha, which indicates a loss of approximately the fourth part of the territory within given time period [3].

During the 185 year period of regular archeological excavations, it was revealed that as a result of coastal erosion the partial destruction of such wellknown sites like the Uvarovs basilica and sixbased church occurred. During the severe storms top mark of the wave climb often reaches the symbol of Chersonesus - the medieval basilica - and leads to flooding of excavations located nearby.

The estimates of the cliff retreat rate at the present stage of the Preserve coast development were obtained for the north and north-eastern areas of the ancient settlement sea border [3]. The research were carried out on the basis of the comparative analysis of the plans and schemes, where during the excavations in different years the position of the cliff and coastline boundaries relatively to the preserved architectural details of buildings, as well as the current coast location measurement results, was precisely fixed. Calculated according to the last century data, the mean coastal retreat rate in the northern section of the ancient settlement amounts to $0.23-0.25 \mathrm{~m} / \mathrm{year}$, and the maximum rate has been fixed near the Uvarov basilica and reaches $0.48 \mathrm{~m} /$ year.

Thus, we can state that the most important archaeological sites, subjected to intense destruction, are located in the northern section of the ancient settlement coast, where there are the greatest rates of cliff abrasion that allows selecting this 
sector as the priority one in need of carrying out the complex coastal protection measures.

Methods of calculation and the input parameters of the model. In the study of the spatial distribution of wind wave characteristics, the SWAN (Simulating WAves Nearshore) wave model, based on the numerical solution of the wave energy balance equation in spectral form, was applied [4]. The mathematical formulation of the problem and solution method used in this paper for modeling of wave fields in the Black Sea waters off the Chersonesus coast, is described in [5].

In the calculations the SWAN model parallel version implemented on a Marine Hydrophysical Institute RAS computing cluster was used. With respect to frequency coordinate the grid consisting of 31 nodes and covering $0.02-2 \mathrm{~Hz}$ range was set. Angular resolution in determining the wave spectrum was $10^{\circ}$. Bottom friction was set according to the Grant - Madsen model with a bottom surface roughness coefficient of $\kappa_{v}=0,05 \mathrm{~m}$. Energy dissipation due to wave breaking on the critical depth was taken into account in the model by $\gamma=0.73$ coefficient, which characterizes the ratio of the wave height to the depth at a given point.

During the parameterization process of the waves passing above an underwater obstacle the following relation for the attenuation coefficient was applied [4]:

$$
K_{t}=-0,4\left[(h-d) / H_{s}\right]+0,64\left(B_{k} / H_{s}\right)^{-0,31}\left(1-\mathrm{e}^{-0,5 \xi_{p}}\right) .
$$

where $d$ the depth from the sea surface to the bottom; $h$ the depth from the obstacle crest to the bottom; $B_{k}$ the width of the crest of the obstacle; $\xi_{p}=\operatorname{tg}\left(\alpha / \sqrt{H_{s} / L_{0 p}}\right)$ is the parameter of breaking, $\alpha$ is a constant depending on the shape of obstacles, $H_{s}$ is the significant wave heights in deep water, $L_{0 p}$ is the wavelength in deep water.

In the construction of the spatial scheme of the calculations a five-step algorithm using nested grids with different spatial resolution was applied [5]. The first three grids, previously used in the modeling of wind waves in the Black Sea $[6,7]$ were its basis. The use of this algorithm allows carrying out the numerical modeling of wave fields with high spatial resolution for the limited area without any loss due to wave processes in the adjacent waters. In the last step on the calculations for the waters off the Chersonesus coast the rectangular grid with a $3 \mathrm{~m}$ spatial resolution was used.

Results and Discussions. In the first stage of the research the calculations of the spatial distribution of wind wave parameters off the Chersonesus coast under different wind directions and speeds were carried out. Its results were pre-analyzed in [5]. Within the active wave effect sector in the range of $270-360^{\circ}$, the model wind of five directions (east, west, northeast, northwest, north-north-west and north) was preset, and further the generation of waves by south-western wind was examined. For medium gales $15 \mathrm{~m} / \mathrm{s}$ speed was preset, and for the extreme ones, observed at least once a year $-25 \mathrm{~m} / \mathrm{s}$.

Comparing the calculation results obtained for the considered speeds of model wind, we are to note the following main features of the formation of wind wave fields off the Tauric Chersonesus coast.

The spatial distribution of the heights of storm waves in the studied water area has the characteristics and essentially depends on the bottom relief at all the considered wind directions. The interaction of the waves with the bottom elevation in the north-western part of the computational domain is manifested in the increase of the amplitude along with the simultaneous decrease of their length. 
Changing of the storm wind direction within the active wave sector boundaries has no significant effect on the overall structure of the fields of the developed wind waves, forming directly off the coast of the Preserve, which is due to the predominant influence of the refraction effects during entrance of the waves in shallow waters. Consequently, with the spread on the landward side and the depth reduce the trend towards the wave front orientation parallel to the isobaths is intensifying.

At the same wind speed the most intense high sea is generated under the northwestern winds, which can be considered the most dangerous because of the increase in the intensity of the wave loads on the Chersonesus coast.

Spreading to the coast the decay of large amplitude waves, developing at $25 \mathrm{~m} / \mathrm{s}$ wind speed, is more intense than the one of waves formed by the wind at $15 \mathrm{~m} / \mathrm{s}$ speed. If at $100-150 \mathrm{~m}$ offshore distance a significant difference between wave heights which are generated using set model wind speeds remains, at $40-$ $70 \mathrm{~m}$ offshore distance a more rapid decrease of the heights of greater amplitude waves will occur. As a result, the wave heights reaching the coastline calculated under 15 and $25 \mathrm{~m} / \mathrm{s}$ wind speeds, differ less considerably than in the seaward side of the water area.

The results of calculations for the north-western wind at $25 \mathrm{~m} / \mathrm{s}$ speed are shown in Fig. 1, where the aforementioned features of the spatial distribution of wave heights can be found. In the narrow strip adjacent to the coast, the shoaling waves are of about 2.1-2.3 m height. The height of waves reaching the water line is an average of $1.5 \mathrm{~m}$. Thus, we can assume that during the passage of severe storms of low repeatability, the coastal cliffs, located in the northern sector of the Chersonesus sea boundary are exposed to dynamic loads resulting from breaking of the waves having height of 1.5 to $2 \mathrm{~m}$.

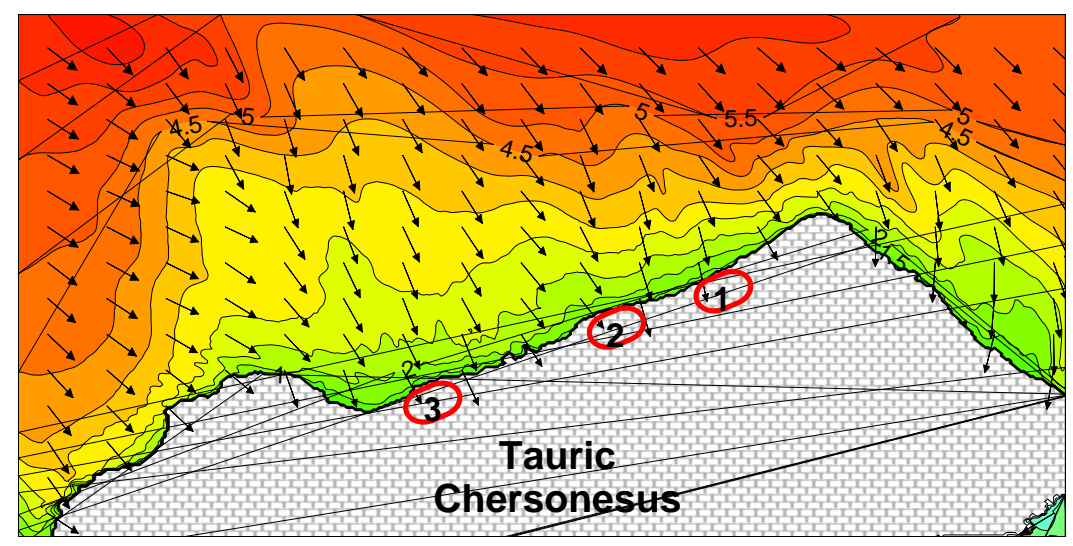

Fig. 1. The spatial distribution of heights $(\mathrm{m})$ and the direction of propagation of the waves off the Chersonesus coast with the north-western wind at $25 \mathrm{~m} / \mathrm{s}$ speed (1 - Uvarov basilica, 2 - sixbased church, 3 - medieval basilica)

At the second stage of the research, a series of numerical experiments on modeling of the wind wave fields under various schemes of spatial arrangement of the hydrotechnical structures in the Chersonesus ancient settlement waters was carried out. Drawing schemes of the coastal protection structures as the main construction elements, designed to provide energy dissipation of the storm waves 
reaching the shore, the submerged breakwaters, located subparallel to the coastline at some distance from it, were considered.

Breakwaters were defined as the $5 \mathrm{~m}$ wide vertically rectangular watertight obstacle. Deepening crest of the each breakwater was assumed to be $1.5 \mathrm{~m}$ relative to the undisturbed sea surface. In the process of the model adaptation the verification of the sensitivity of simulation results to the set width of the underwater obstacles was carried out. Calculations showed that the reduction of the breakwater width to $3 \mathrm{~m}$ had almost no effect on the results, and the increasing up to $15 \mathrm{~m}$ reduced the calculated values of wave heights in behind-the-breakwater space by 20 - 25\% maintaining the qualitative structure of wave fields.

During a series of numerical experiments the length and number of breakwaters, as well as the distance from the coast to the place of their location, varied. The possibility of the incorporation of the watertight groins being mainly the beachholding structures was additionally taken into consideration. As a driving force in all numerical experiments the $25 \mathrm{~m} / \mathrm{s}$ north-western homogeneous wind was defined.

Initially, we are to consider the calculation results obtained for the most common ways of allocation of the breakwaters. Fig. 2, $a$ shows the results of calculation of the field of the significant wave heights for the underwater obstacle allocation scheme according to the detached breakwater type. The system consists of three breakwaters, which are located parallel to the coast at an average distance of about 50 meters from the waterline. The length of the breakwaters is $120 \mathrm{~m}$ (the west one) and $130 \mathrm{~m}$ (the central and eastern ones). The distance between the obstacles is 55 and $40 \mathrm{~m}$, respectively.

From the seaward part of the water area the $2.2-2.7$ m waves run up almost normally to the coastal protection structures. The sea surface oscillation amplitude increases in the direction from the west to east. Immediately after passing through the breakwaters the wave heights sharply reduced to $0.6-0.7 \mathrm{~m}$ on the almost entire length of the obstacles. However, the field of wave heights, generating in the behind-the-breakwater area located closer to the coast has significant heterogeneity. This is largely due to the possibility of unimpeded passing of the waves through the gaps between the breakwaters. As a result, the waves having height up to $1.0-1.3 \mathrm{~m}$ can run up in these areas closer to the coast. Approaching the coastline the width of the water area with wave heights over $1 \mathrm{~m}$ slightly increases, due to the effect of the diffraction of waves bending around the points of the breakwaters.

In the areas situated in the central part of the wave shading zones generated by the central and western breakwaters, the effect of a certain increase of wave heights up to $0.8 \mathrm{~m}$ is additionally observed in waterline strip.

The results of numerical experiments show that the application of the aforementioned scheme of the coastal protection structure allocation in behind-thebreakwater space causes the 3 times decrease of the significant wave heights. This primarily demonstrates the effectiveness of the wave shading action of the underwater breakwaters having the significant deepening of the crest, under the considered values of heights of the waves running up from the seaward part of the water area. Passing of the waves through the gaps between the breakwaters is accompanied by some increase in the wave load on the short segments of the 
protected section of the coast, which if necessary can be minimized by moving structures in the alongshore direction.

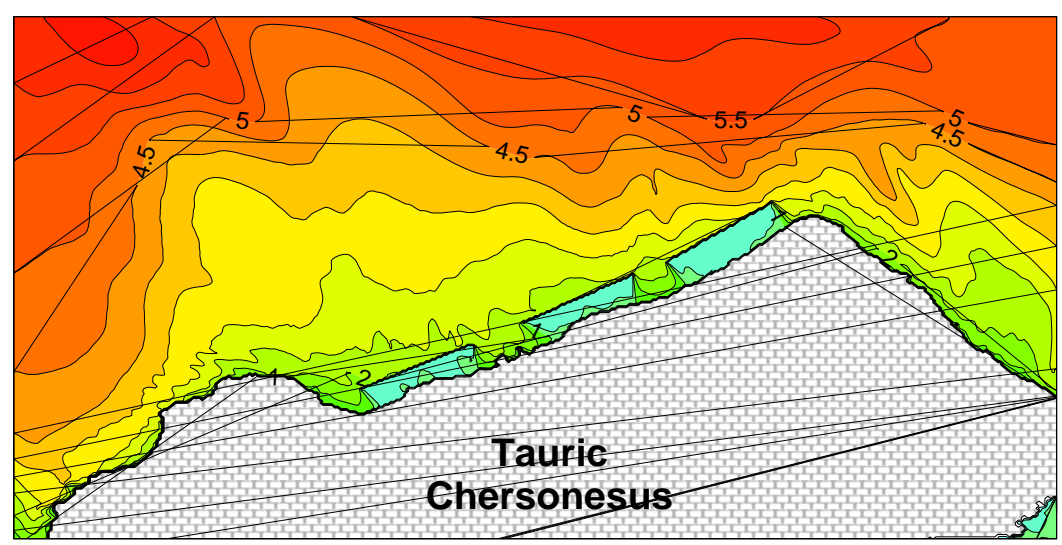

$a$

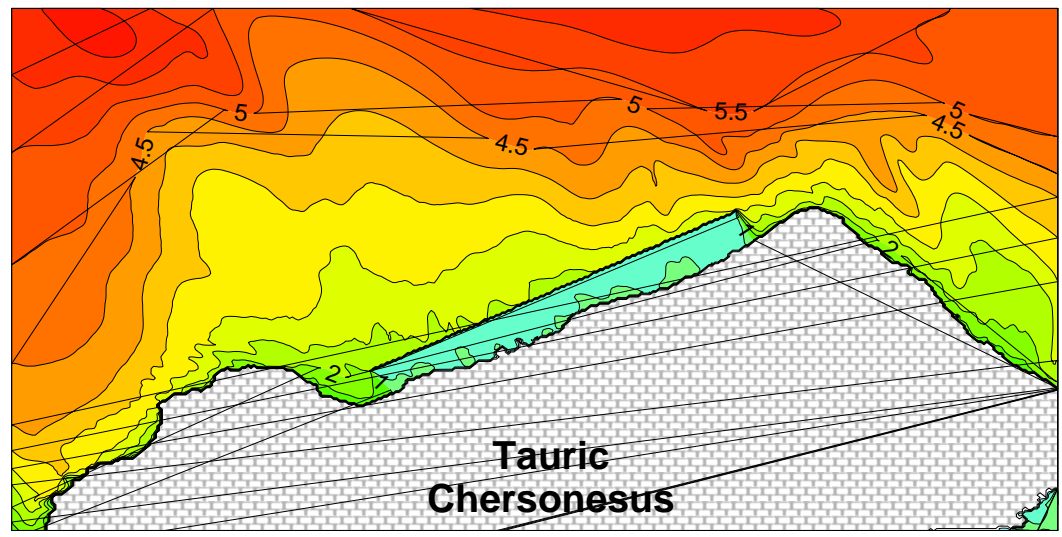

Puc. 2. Spatial distribution of the wave heights ( $h$ ih) under the allocation of the detached $(a)$ and solid (b) submerged breakwaters

The following experiment deals with the case of accommodation of one solid $420 \mathrm{~m}$ length breakwater parallel to the shoreline general direction at an average distance of about 50 meters from the waterline (Fig. 2, b). Waves approaching the obstacle have the same features as in the previous experiment.

Height of the waves behind the obstacle is reduced to $0.6-0.65 \mathrm{~m}$. At the same time, due to the continuity of the breakwater, the zones of the unimpeded wave propagation to the water line disappear. At the edges of the breakwater a slight narrowing of the wave shading strip due to the diffraction of waves is marked. This experiment also demonstrates the zones of small increase (10 $15 \mathrm{~cm}$ ) of the wave heights in the waterline area. The proximity of their shape and location to those observed in the first experiment, and, consequently, the relative independence of the obstacle shape allow us to consider the process of the wave amplitude local increase to be primarily caused by their interaction with the bottom topography. 
Allocation of the solid breakwater leads to the formation of a continuous strip of substantially weakened waves. The height of the waves running up directly to the appropriate shore decreases almost 3 times. From the viewpoint of protection of the damaged sections this scheme of coastal protection structure allocation is more effective than the one considered in the first case. However, it remains an open issue related to the water exchange features between the behind-the-breakwater strip and adjacent waters during periods of calm.

Further we are to analyze the results of the calculations for the case of allocation of three submerged breakwaters in the "checkerboard" manner when the central one is shifted towards the coast (Fig. 3,a). The east and west breakwaters have a length of 170 and $175 \mathrm{~m}$, respectively, and are located at a distance of about $90 \mathrm{~m}$ from the coast. The central $175 \mathrm{~m}$ length breakwater is located at a distance of about 50 meters from the waterline. The distance between the east and west breakwaters is $150 \mathrm{~m}$ and results in partial overlapping of the projections of the breakwaters on the general direction of the shoreline.
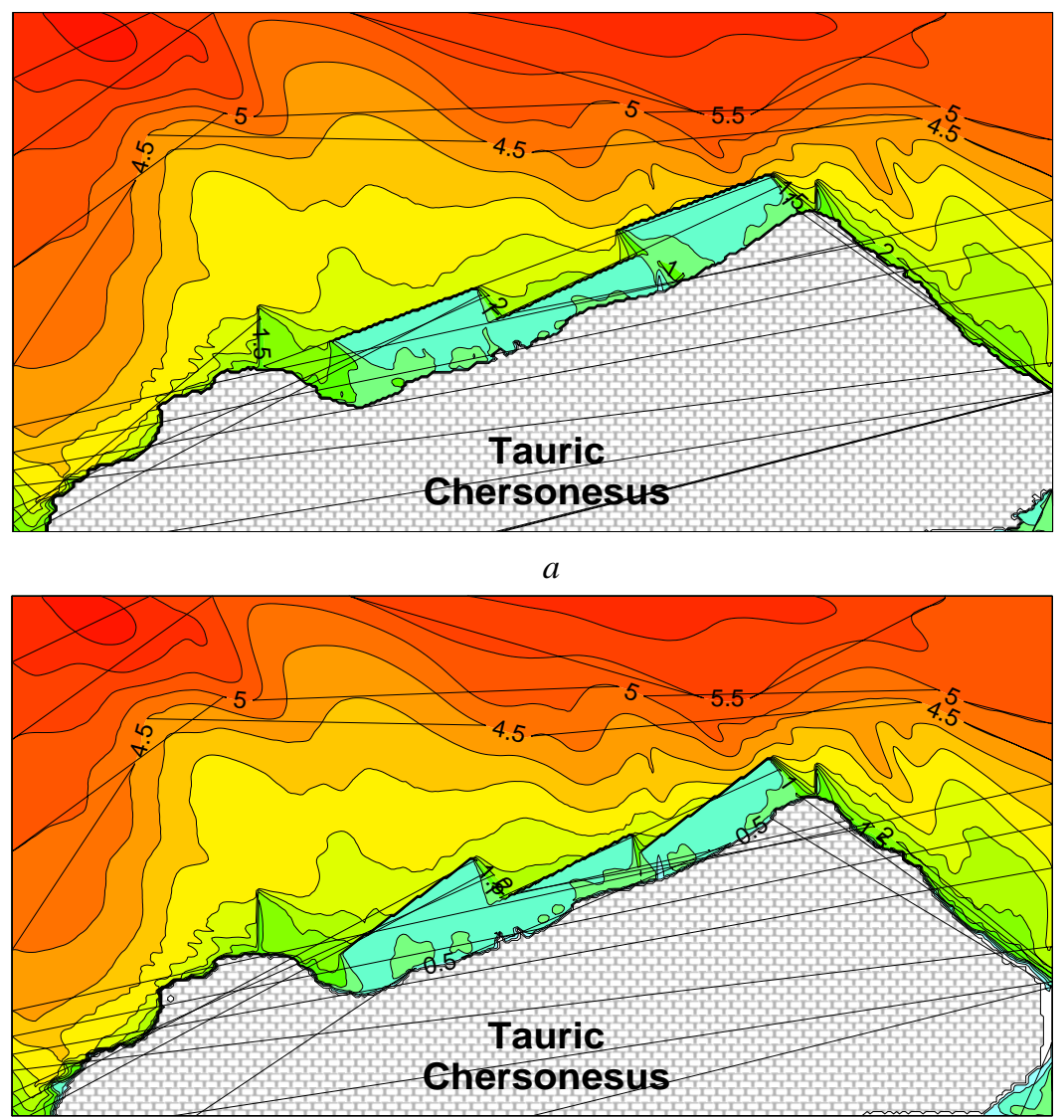

$b$

Fig. 3. Spatial distribution of the wave heights $(\mathrm{m})$ with three groins and the allocation of the submerged breakwaters in the "checkerboard" $(a)$ and the "step" $(b)$ order 
Each of the breakwaters causes quite an effective decrease of wave heights directly behind the obstacle up to the values of $0.6-0.7 \mathrm{~m}$. We can observe the formation of a substantially continuous wave shading zone in the space behind the breakwaters where the wave height does not exceed $0.7 \mathrm{~m}$. In the waterline area the wave heights do not exceed $0.6-0.8 \mathrm{~m}$. Thus, all three damaged areas of the coastline in the northern part of Chersonesus ancient settlement, where the destruction of archaeological sites is currently in process (Fig.1), can be adequately protected from the strong storm waves.

In addition, it is assumed that the allocation of breakwaters in the "checkerboard" manner parallel to the coast at different distances from it, in addition to a sufficiently high efficiency of wave energy dissipation near the shore, will provide more favorable conditions for water exchange with the surrounding water area.

The following numerical experiment covers the "stepped" allocation of the breakwaters, where the east and west ones are situated at an angle to the principal direction of the coastline, so the distance from the shore to their western ends is less than to the eastern ones (Fig. 3, $b$ ). The east breakwater has a length of $180 \mathrm{~m}$, the west one $-185 \mathrm{~m}$, while the central one $-155 \mathrm{~m}$. The distance from the coast to the ends of the east obstacle is 60 and $110 \mathrm{~m}$, and the distance to the ends of the west one - 45 and $65 \mathrm{~m}$. The central breakwater is located almost parallel to the coast at a distance about 60 meters from the waterline. In this case, as in the previous variant, the condition of partial overlapping of the projections of the breakwaters at the general direction of the coastline is observed.

Applying this scheme of the coastal protection structure allocation the formation of a practically continuous wave shading zone in space behind the breakwaters is observed. Immediately after passing underwater obstacles the wave heights do not exceed $0.75 \mathrm{~m}$. The area between the central and east breakwaters with the $1 \mathrm{~m}$ height oscillations is substantially limited. In the water line strip the wave heights are $0.6-0.8 \mathrm{~m}$, which provides reliable protection for the entire coast area from the effects of a strong storm waves.

As for the provision of the water exchange with the adjacent water area, it is assumed that the allocation of the west and east breakwaters at a slight angle should contribute to the creation of more favorable conditions for the water circulation in the space behind the breakwaters during the alongshore current generation under the influence of the eastern and north-eastern winds of great repeatability, that, however, do not cause the large-amplitude waves.

In the last two numerical experiments three groins are included in the coastal protection system (Fig. 3). The west groin has a length of $70 \mathrm{~m}$, the east one 40 meters, and the groin placed in the central part of the area $-35 \mathrm{~m}$.

It is assumed that the east and west groins located on headland projections, restrict the zone of the potential alongshore drift of sediments in order to minimize the possibility of the irrevocable removal of beach forming material outside the lithodynamic cell of the research area. This is especially important in creation of the artificial beach using nourishment technique. The central groin is regarded as a beach forming construction, located in the western part of the currently existing attached beach. 
According to the calculations, the east and west groins influence the formation of the wave field in the waterline strip, leading to a slight decrease in the wave heights as a result of the formation of additional sections of wave shading (Fig. 3). At the same time, the overall pattern of the distribution of wave heights in the waterline zone becomes more complicated.

Construction of the groins is not a mandatory element of the considered coastal protection system, since it is assumed that dissipation of a significant part of the storm wave energy will occur due to the interaction with underwater obstacles. It will result in the propagation of considerably weakened waves to the waterline, and the creation of the artificial beach of little width will be enough for the further dissipation of the energy of those waves. However, during operation of this beach the necessity of the cross-shore beach-holding structures may appear. In this case, it is recommended to use the groins, allocated according to the scheme applied in the calculations. The length of the groins and their elevation points relatively the undisturbed sea surface can be determined taking into account the planned amounts of the material used for beach nourishment and its features. As the main structural elements the low height rubble-mound groins with dense laying stone on the surface are supposed to be used, including the formation of the arcshaped cross-section profile. This will significantly increase the groin stability to the destruction caused by wind waves and also organically fit these constructions in the natural landscape.

Conclusions. Use of the submerged breakwaters as the main construction elements to create the coastal protection system of the Preserve Tauric Chersonesus will permit to keep the historical landscape of the ancient settlement shores and the adjacent sea area.

The performed research of the field of wave heights at various schemes of submerged breakwater allocation along the northern section of the Chersonesus ancient settlement sea border showed the possibility of effective storm wave energy dissipation by the breakwaters the crest of $3-5 \mathrm{~m}$ width and their $1.5 \mathrm{~m}$ deepening relatively undisturbed sea surface.

Calculations showed that at the wind speed of $25 \mathrm{~m} / \mathrm{s}$ of the most wavegenerating northwest direction the height of waves reaching the unprotected ancient settlement shores is $1.5-2 \mathrm{~m}$. After allocation of the coastal protection system consisting of three submerged breakwaters located in the strip $50-90 \mathrm{~m}$ from the coast, the height of the waves reaching the waterline reduced to an average of $0.7-0.8 \mathrm{~m}$.

Allocation of three submerged breakwaters subparallel to the shore in the "checkerboard" and "step" order provides almost complete coverage of the protected damaged coastal area of the Preserve by wave shading zone. At the same time the principle of partial overlapping of the projections of the breakwaters at the general direction of the coastline should be observed. It is also expected that applying the aforementioned schemes of the breakwater spatial distribution will create the most favorable conditions for the water exchange with the adjacent water area.

If there appears the necessity to create the beach-holding constructions, the rubble-mound groins with dense laying stone on the surface are supposed to be used, including the formation of the arc-shaped cross-section profile.

Acknowledgements. The research was carried out under the support of the RFBR Grant No. 14-45-01603. 


\section{REFERENCES}

1. 1998, "Proektirovanie morskikh beregozashchitnykh sooruzheniy SP 32-103-97 [Code of rules 32-103-97. Design of coast protection structures]”, Moscow, Transstroi, 166 p. (in Russian).

2. Romashchenko, M.I., Lyashevs'kiy, V.I. \& Voytovich, I.V. [et al.], 2011, “Beregoukriplennya drevn'ogo gorodishcha «Khersones Tavriys'kiy» [Coastal protection of ancient settlement Tauric Chersonesus]", Ekologicheskaya bezopasnost' pribrezhnoy i shel'fovoy zon i kompleksnoe ispol'zovanie resursov shel'fa, iss. 25, pp. 111-116 (in Ukrainian).

3. Lebedinskiy, V.V., Pronina, Yu.A., 2013, "Issledovanie drevney beregovoy linii Khersonesa Tavricheskogo i ego khory [Study of the ancient coastline of Tauric Chersonesus and its Chora]”, Pidvodni doslidzhennya: Arkheologiya. Istoriya. Dayving, iss. 5, pp. 145-153 (in Russian).

4. 2012, “SWAN Cycle III version 40.85", User Manual, Delft University of Technology, Netherlands, 119 p. (http://swan.ct.tudeft.nl).

5. Mikhaylichenko, S.Yu., 2014, "Issledovanie rezhimov shtormovogo volneniya $v$ akvatorii Khersonesa [Research of storm wave regime in the water area off Chersonesus ]", Ekologicheskaya bezopasnost' pribrezhnoy i shel'fovoy zon i kompleksnoe ispol'zovanie resursov shel'fa, iss. 29, pp. 22-30 (in Russian).

6. Alekseev, D.V., Fomin, V.V. \& Ivancha, E.V. [et al.], 2012, “Matematicheskoe modelirovanie vetrovogo volneniya $v$ Sevastopol'skoy bukhte [Mathematical modeling of wind waves in the Sevastopol Bay]”, Morskoy gidrofizicheskiy zhurnal, no. 1, pp. 75-84 (in Russian).

7. Alekseev, D.V., Ivanov, V.A. \& Ivancha, E.V. [et al.], 2013, “Otsenka vliyaniya zashchitnykh molov na kharakteristiki vetrovogo volneniya $v$ Sevastopol'skoy bukhte [Estimation of the effect of protective piers on wind wave parameters in the Sevastopol Bay]", Meteorologiya $i$ gidrologiya, no. 4, pp. 47-57 (in Russian). 